УДК $630 * 37$

DOI: 10.34220/2311-8873-2020-3-3-164-190

АНАЛИЗ ЭФФЕКТИВНОСТИ ВЫВОЗКИ ЗАГОТАВЛИВАЕМЫХ ЛЕСОМАТЕРИАЛОВ РАЗЛИЧНЫМИ ВИДАМИ ТРАНСПОРТА НА СОВРЕМЕННОМ ЭТАПЕ РАЗВИТИЯ РФ

Никонов В.О., Посметьев В.И.

Федеральное государственное бюджетное образовательное учреждение высшего образования «Воронежский государственный лесотехнический университет им. Г.Ф. Морозова»

Email: 8888nike8888@ mail.ru

Аннотация: В статье рассмотрены особенности транспортирования лесоматериалов различными видами транспорта, используемыми в настоящее время в РФ. Приведены условия их применения с учетом доступности используемых транспортных путей, а также возможностей региона. Описаны основные конструктивные особенности этих видов транспорта. Представлены наиболее важные преимущества использования для вывозки лесоматериалов автомобильного транспорта в сравнении с сухопутным, водным, трубопроводным и воздушным транспортом.

Ключевые слова: эффективность, современный транспорт для вывозки лесоматериалов, автомобильный и железнодорожный транспорт, водный и трубопроводный транспорт, аэростат, дирижабль, вертолет, вертостат.

\title{
ANALYSIS OF THE EFFICIENCY OF TRANSPORTATION OF PROCESSED \\ TIMBER MATERIALS BY VARIOUS TYPES OF TRANSPORT AT THE CURRENT STAGE OF DEVELOPMENT OF THE RUSSIAN FEDERATION
}

Nikonov V.O., Posmetev V.I.

Federal State Budgetary Educational Institution of Higher Education «Voronezh State Forestry University. G.F. Morozova»

Email: $\underline{\text { 8888nike8888@ mail.ru }}$

Summary: The article discusses the features of the transportation of timber by various types of transport currently used in the Russian Federation. The conditions for their application are given, taking into account the availability of the used transport routes, as well as the capabilities of the region. The main design features of these types of transport are described. The most important advantages of using road transport for hauling timber in comparison with land, water, pipeline and air transport are presented.

Keywords: efficiency, transport for hauling timber, road and rail transport, water and pipeline transport, aerostat, airship, helicopter, helicopter. 


\section{Введение}

Важное место в экономике нашей страны занимает ее лесной комплекс, состоящий из таких основных хозяйственных сфер, как лесного хозяйства и лесной промышленности. В технологическом процессе лесопромышленного производства вывозка лесоматериалов в большинстве случаев является решающим звеном, которое во многом определяет эффективность работы лесозаготовительных предприятий и варианты их связей с потребителями. Являясь одной из наиболее дорогостоящих технологических операций в производственном процессе заготовки лесоматериалов, их вывозка имеет огромное экономическое значение.

Главная роль в вопросе обеспечения эффективности вывозки лесоматериалов принадлежит проблеме выбора требуемого вида транспорта. В процессе осуществления вывозки лесоматериалов задействованы различные виды транспорта, использование которых во многом зависит от его технико-экономических особенностей, размещения транспортной инфраструктуры по территории страны, географического месторасположения лесов, их равномерности распределения, объема и характеристик заготавливаемых лесоматериалов, территориального расположения лесозаготовительных предприятий, а также предприятий деревообрабатывающей и целлюлозно-бумажной промышленности, наличия данного вида транспорта непосредственно в месте заготовки лесоматериалов, а также стоимости, времени вывозки и других показателей, характеризующих качество функционирования данного вида транспорта [1].

Выявление основных особенностей использования различного вида транспорта в процессе вывозки лесоматериалов, а также сравнение существенных преимуществ при применении лесовозного автомобильного транспорта (ЛАТ), является актуальной задачей, требующей незамедлительного решения.

\section{Цель исследования}

Целью исследования является анализ существующих научных статей и материалов в области существующих видов транспорта, используемого в процессе вывозки лесоматериалов, а также сравнительная оценка эффективности применения лесовозного автомобильного транспорта.

\section{Материал и методы исследования}

Исследование выполнено на основании изучения российской и зарубежной научной литературы, содержащей информацию о различных видах транспорта, используемого для вывозки лесоматериалов. 


\section{Результаты исследования и их обсуждение}

Транспорт для вывозки лесоматериалов относится к промышленному транспорту, осуществляющему доставку лесоматериалов в виде сырья на лесозаготовительные предприятия, вывозку лесоматериалов с лесозаготовительных предприятий, а также обеспечивающему связь между отдельными лесозаготовительными предприятиями и потребителями. В настоящее время для вывозки заготовленных лесоматериалов применяются различные виды транспорта (рис. 1). Среди них выделяют сухопутный, воздушный, водный и трубопроводный транспорт, а также их разновидности.

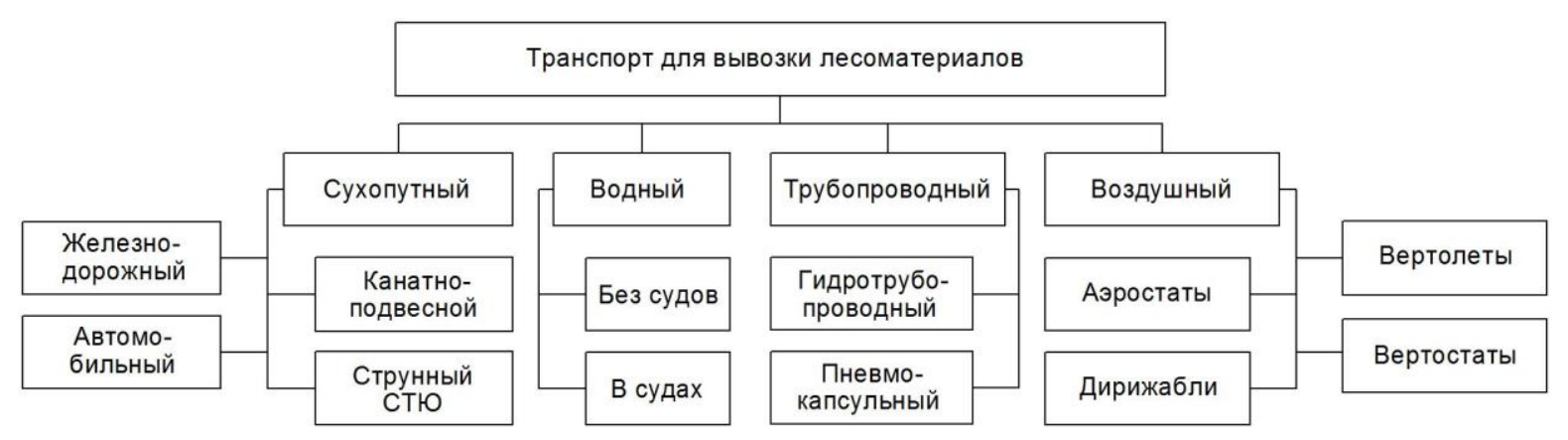

Рисунок 1 - Разновидности транспорта, используемого для вывозки лесоматериалов

Применение того или иного вида транспорта для вывозки лесоматериалов зависит от возможностей и месторасположения региона, доступности транспортных путей. Так в регионах, не имеющих выходы к крупным рекам или морям, но обладающим развитой сетью железных и автомобильных дорог, вывозку лесоматериалов выгоднее выполнять наземным видом транспорта. В регионах, имеющих развитую морскую инфраструктуру с выходами и к рекам и морям, вывозку или транспортировку лесоматериалов экономичнее осуществлять водным видом транспорта. Для выявления основных особенностей функционирования существующих видов транспорта, используемых в процессе вывозки или транспортировки лесоматериалов, рассмотрим каждый из них по отдельности более подробно.

В районах Севера, Урала и Сибири места лесозаготовок удалены настолько, что осуществить транспортирование лесоматериалов с нижних складов в пункт потребления, переработки или перевалки железнодорожным транспортом или ЛАТ просто невозможно, и прокладывать туда ЛД, в том числе железнодорожные пути слишком затратно, а наличие водных путей, допускающих транспортирование лесоматериалов, в таком случае является наиболее целесообразным способом. Недостатком этого способа является отсутствие всесезонности и возможные негативные экологические последствия от загрязнения водных путей. 


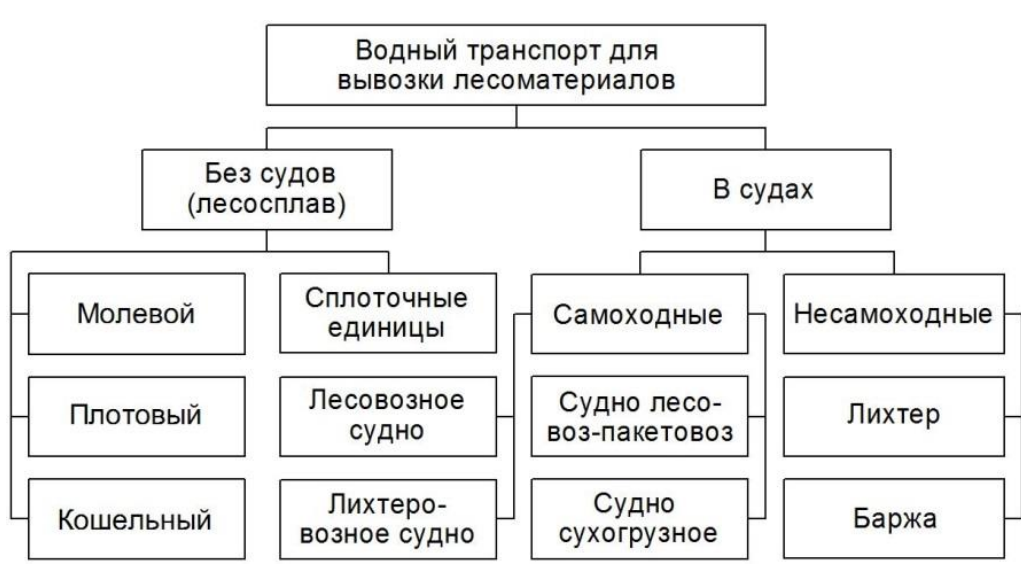

Рисунок 2 - Разновидности водного

транспорта, используемого при транспортировании лесоматериалов
К водному транспорту относят совокупность технических и технологических мероприятий, позволяющих осуществлять транспортирование или вывозку лесоматериалов по внутренним водным путям, включающим в себя реки, озёры и каналы, а также по морским водным

путям. Используемые для транспортирования лесоматериалов по водным путям транспортно-технологические схемы подразделяются по типу лесосплава на кошельный, молевой, плотовой, сплоточные единицы и по типу используемых судов на самоходные (лесовозы, лихтеровозы, лесовозы-пакетовозы, сухогрузные судна) и несамоходные (лихтеры и баржи) судна (рис. 2).

В РФ водный транспорт, передвигающийся по морским водным путям (морям), относится и к внутреннему транспорту, и к внешнему, осуществляющему транспортировку грузов в международном сообщении. По состоянию на 2020 г. структура морского транспортного комплекса РФ включает в себя 67 морских портов. Из них на транспортировании лесоматериалов специализируются: Азов, Ростов-на-Дону, Таганрог, Новороссийск, Выборг, Санкт-Петербург, Оля, Петропавловск-Камчатский, Корсаков, Москалево, Охотск, Поронайск, Ванино, Владивосток, Восточный, Де-Кастри, Находка, Ольга, Архангельск, Онега, Певек, Дудинка, Игарка, Беринговский, Эгвекинот. Основными водными путями для внутреннего водного транспорта древесины являются реки, которые объединены в следующие бассейны: Северо-Двинский, Волжско-Камский, Обь-Иртышский, Ангар-Енисейский, Ленский, Байкальский и Амурский [2].

Транспортирование лесоматериалов водным транспортом является одним из самых недорогих способов вывозки. Для перемещения лесоматериалов водным транспортом используются готовые водные пути и по сравнению с ЛАТ и железнодорожным транспортом оно дешевле в 15-20 и 10 раз соответственно. Это объясняется тем, что содержание и обслуживание водных путей требует меньше материальных затрат, в сравнении с другими видами транспорта. Главной образующей водного транспорта лесоматериалов является лесосплав, при кото- 
ром используются свойства плавучести древесины, за счет которой данный способ транспортирования лесоматериалов является менее затратным в пункты доставки, где они перегружаются для дальнейшей вывозки на другие виды транспорта.

Лесосплав подразделяется на первоначальный и магистральный. При первоначальном лесосплаве, осуществляемом по небольшим рекам, каналам и лесосплавным лоткам, лесоматериалы перемещаются из глубины лесных массивов к водным и железнодорожным магистральным путям. Длительность транспортирования лесоматериалов таким способом занимает от 5 до 40 дней. Последующая подготовка лесоматериалов к их транспортированию по воде или по суше выполняется в лесных рейдах, которые организуются в пунктах примыкания путей первоначального сплава к водным или железнодорожным магистральным путям [3].

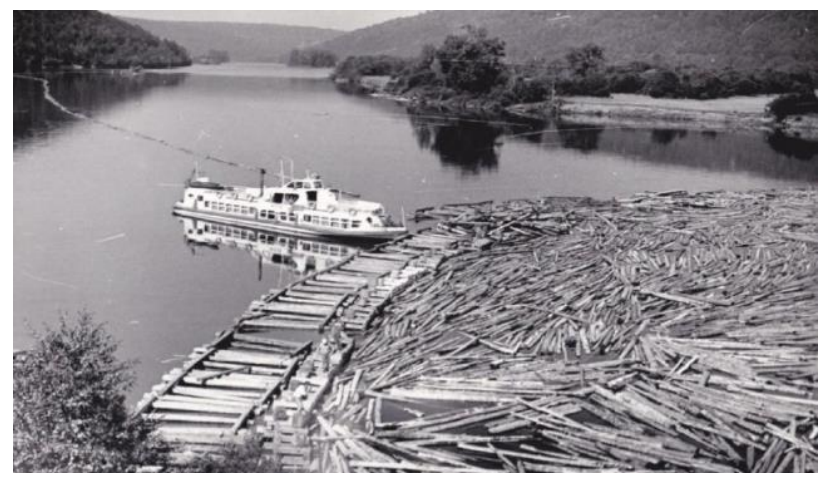

Рисунок 3 - Молевой лесосплав

Исходным типом лесосплава, с помощью которого ранее начиналось транспортирование заготовленного лесоматериала по водным путям, являлся молевой сплав (рис. 3). Осуществление этого типа лесосплава выполнялось на несудоходных реках, в их верховьях при ограниченной ширине и глубине реки. Заготовленные в лесосеках лесоматериалы доставлялись к сплавным складам, размещенным на небольших водотоках сухопутными видами транспорта. На таких складах часть лесоматериалов размещали штабелями на берегу реки, а другую часть подготавливали к сплаву. Лесоматериалы, никак не связанные между собой или совокупность их, объединенных в специальную сплоточную единицу, в период весеннего паводка россыпью опускали в воду, где они свободно плыли по течению реки. Для направления движения лесоматериалов по лесосплавному ходу устанавливали боновые направляющие, а для частичного или полного прекращения сплава в определенных местах сплавной реки монтировали запани.

Основным недостатком молевого лесосплава являлось его негативное влияние на водотоки, которое приводило к серьезным экологическим последствиям. Многие годы использования рек в качестве путей для молевого лесосплава привели к образованию на их дне толстых прослоек из значительного объема коры и бревентопляков, которые со временем, перегнивая, выделяли большое количество фе- 
нольных химических соединений, оказывающих негативное воздействие на обитание рыб. Привлечение внимания природоохранными ведомствами к данной проблеме государственных служб заняло много лет, и 18.10.1995 г. молевой сплав лесоматериалов был запрещен. Это привело к значительному уменьшению объема транспортируемого лесоматериала по водным путям и стало следствием того, что ведущее положение в процессе транспортирования лесоматериалов по судоходным и временно судоходным рекам занял сплав лесоматериалов в плотах, а по несудоходным - сплав лесоматериалов сплоточными единицами [4].
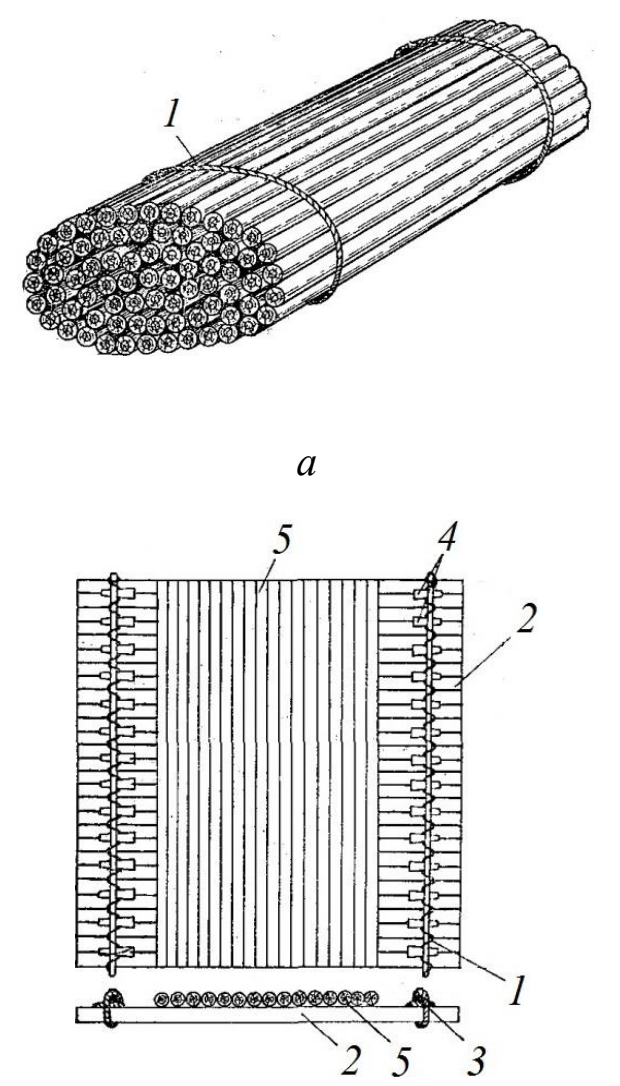

$\sigma$

$a$ - пучок; $\sigma$ - плитка;

1 - обвязка; 2 - нижний ряд бревен; 3 - рамник; 4 - клинья;

5 - второй ряд бревен

Рисунок 4 - Сплоточные единицы

топляемом берегу, то при пуске с помощью специальных подъемнотранспортных средств их сбрасывают в воду для сплава [5].

Перед транспортированием лесоматериалов с помощью плотов, лесоматранспорта леса, относящегося также к первоначальному сплаву, в виде сплоточных единиц позволяет в отличие от молевого лесосплава транспортировать по реке лесоматериалы, собранные в пучки или плитки (рис. 4). Наибольшее применение эта разновидность водного вида транспортирования лесоматериалов нашла в верховьях судоходных рек, а также на несудоходных реках. Кроме этого, сплав лесоматериалов в сплоточных единицах наиболее эффективен при использовании в кратковременный период весеннего паводка и в сплавных реках. Такое использование дает возможность сократить время транспортирования лесоматериалов до крупных сплавных магистралей, а также уменьшить затраты труда и материальных средств. Подготовка сплоточных единиц к сплаву выполняется заранее в течение всего навигационного периода, их укладывают на пониженные берега, защищенные от весеннего ледохода, но затопляемые весенним паводком. Если укладка сплоточных единиц производится на более высоком неза- 


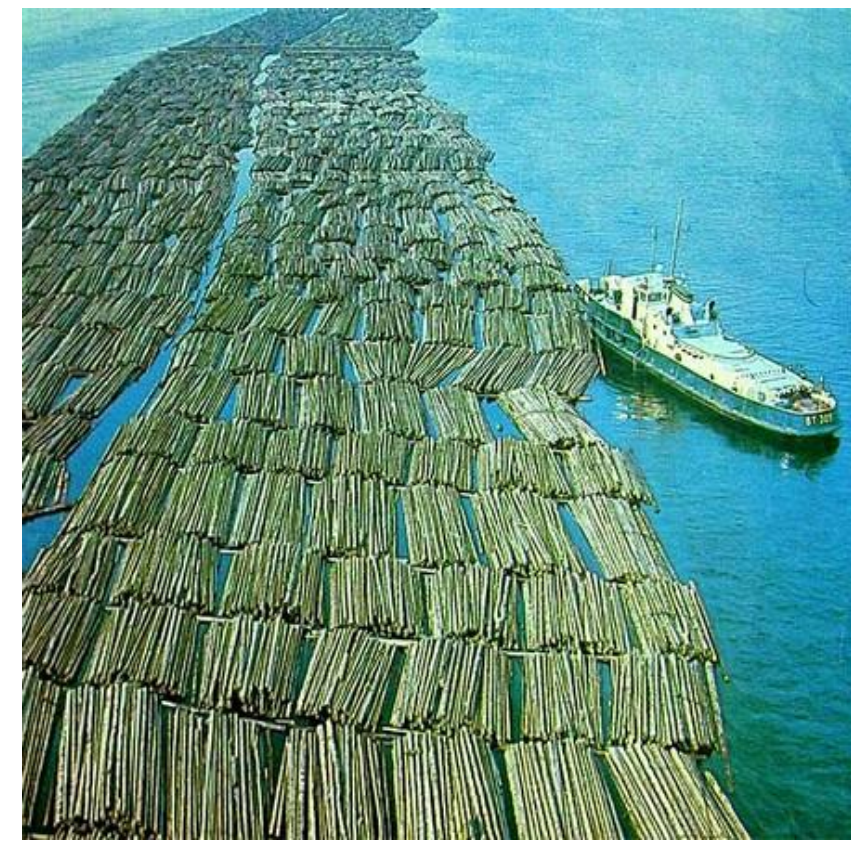

Рисунок 5 - Транспортирование лесоматериалов в плотах териалы соединяются между собой в пучки или плитку, после чего такие плоты при помощи теплоходов или других типов водного транспорта буксируются до пункта назначения (рис. 5). Транспортирование лесоматериалов с помощью плотов может осуществляться как судами поставщика по сплавным путям, так и по судоходным рекам специализированной организацией. Кроме этого, известен еще один вид лесосплава, который используется в случае недостатка буксирного флота. Этот вид лесосплава имеет малую эффективность, редко применяется, и заключается в транспортировании плотов без тяги самосплавом вниз по течению реки, с использованием для его управления специального такелажа $[6,7]$.

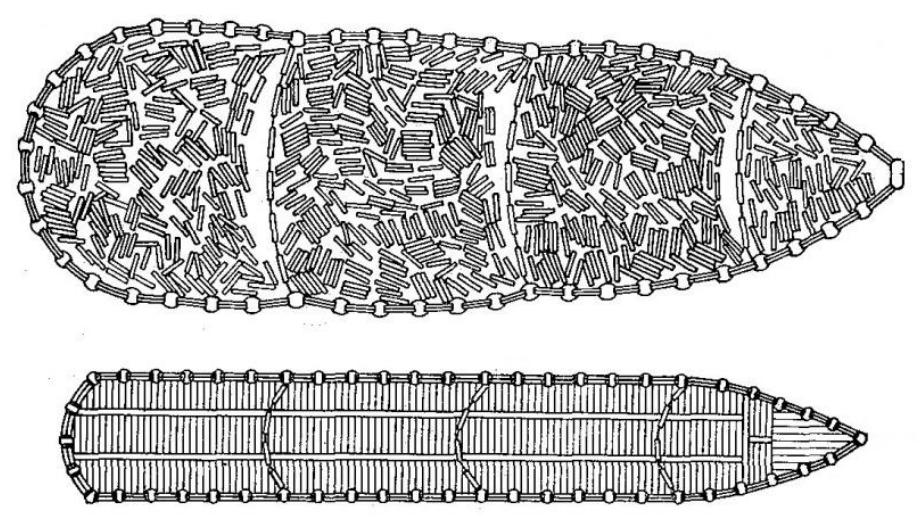

Рисунок 6 - Кошели

Транспортирование лесоматериалов на небольшие расстояния выполняется с помощью кошелей, которые состоят из несвязанных между собой лесоматериалы, обносимых специальными оплотниками. Далее эти кошели перемещаются по воде буксирными судами или катерами. Такой вид лесосплава нашел применение на водохранилищах, озерах, а также участках рек с ограниченными скоростями течения. Обычно объем лесоматериалов в кошеле составляет от 1000 до 5000 $\mathrm{M}^{3}$ и зависит от мощностных характеристик буксируемого судна (рис. 6).

Использование для транспортирования лесоматериалов лесосплава имеет ограничения, которые связаны со следующими его недостатками: низкая скорость транспортирования, зависимая от квалификации сплавщиков, а также скорости течения сплавной реки; частое возникновение заторов лесоматериа- 
лов, образующих непроходимые груды на участках поворотов русла реки или ее порогов, а также требующих для их устранения специализированной техники, доставляемой в место затора по воздуху; высокое влияние на процесс лесосплава быстро изменяющихся природно-климатических условий, гидрологических характеристик рек, а также месторасположение лесозаготовительных и лесоперерабатывающих предприятий.

В сравнении с транспортированием лесоматериалов в плотах, перевозка их в судах может выполняться в больших речных бассейнах, с использованием самоходных судов (рис. 7) и буксирных несамоходных барж (рис. 8). На самоход-
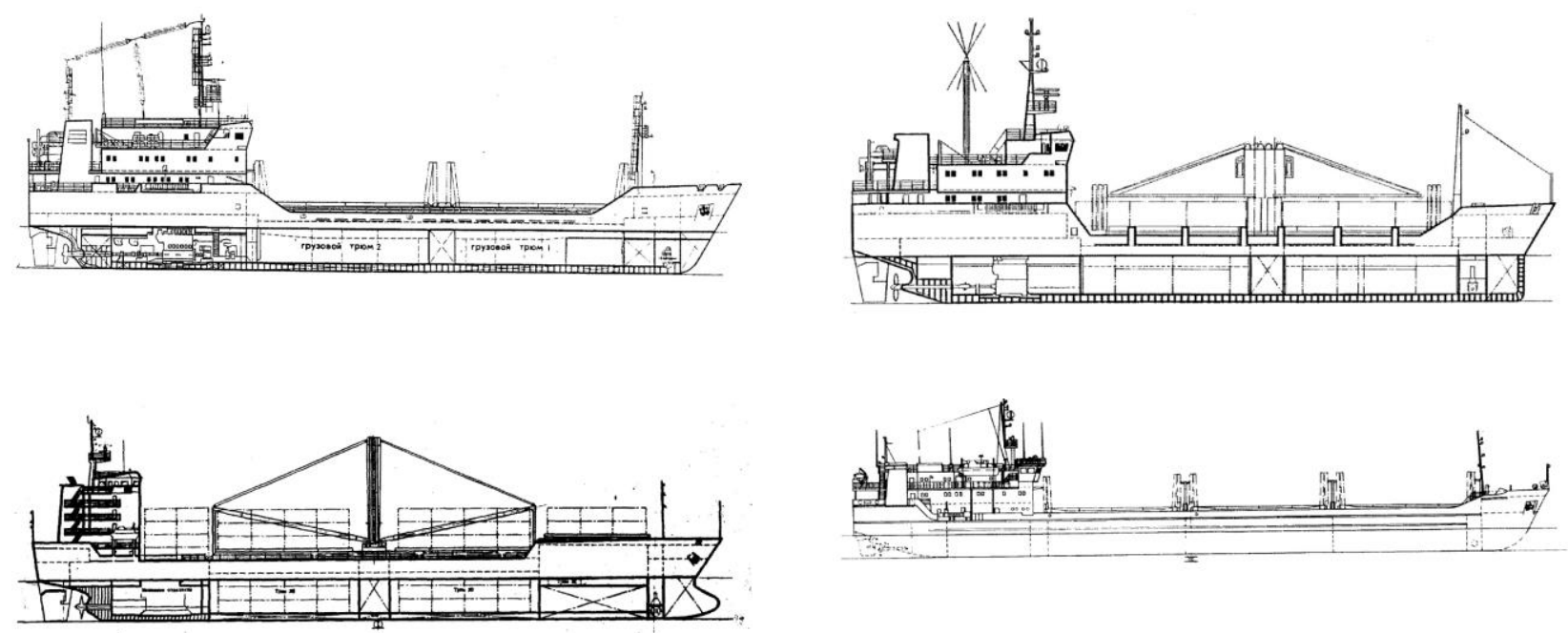

$a$ - лесовоз-пакетовоз дедвейтом 2600 т; $\sigma$ - универсальное сухогрузное судно 1500 т; в - универсальное сухогрузное судно дедвейтом 9000 т; 2 - сухогрузный теплоход 2300-2800 т

Рисунок 7 - Основные типы самоходных судов для перевозки лесоматериалов

ных судах лесоматериалы также могут транспортироваться не только по рекам, но и по крупным озерам, водохранилищам, а также по морям. Для этого используются самоходные суда речного и морского флотов. Транспортирование лесо-

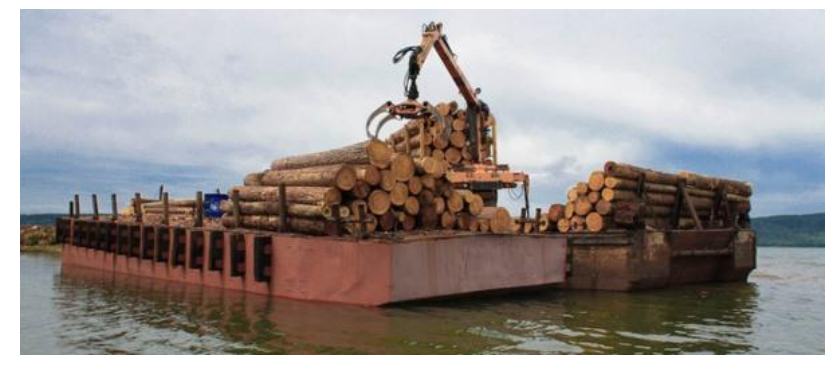

Рисунок 8 - Баржа с лесоматериалами материалов также может выполняться на судах-лесовозах, подразделяемых на обычные лесовозы и лесовозыпакетовозы, а также на универсальные суда. Кроме этого, к каждому типу судов предъявляется комплекс требований по подготовке лесоматериалов, процессу погрузки их на судно, а так- 
же к различным процессам, выполняемым в различных условиях их эксплуатации [8].

В судах лесовозах транспортирование круглых лесоматериалов осуществляется россыпью, а также в пакетах и блок-пакетах (рис. 9). При перевозке леса для полной загрузки судна большую часть груза принимают на верхнюю палубу. Палубу ограждают фальшбортом повышенной прочности и оснащают специальным устройством для крепления верхней палубы.
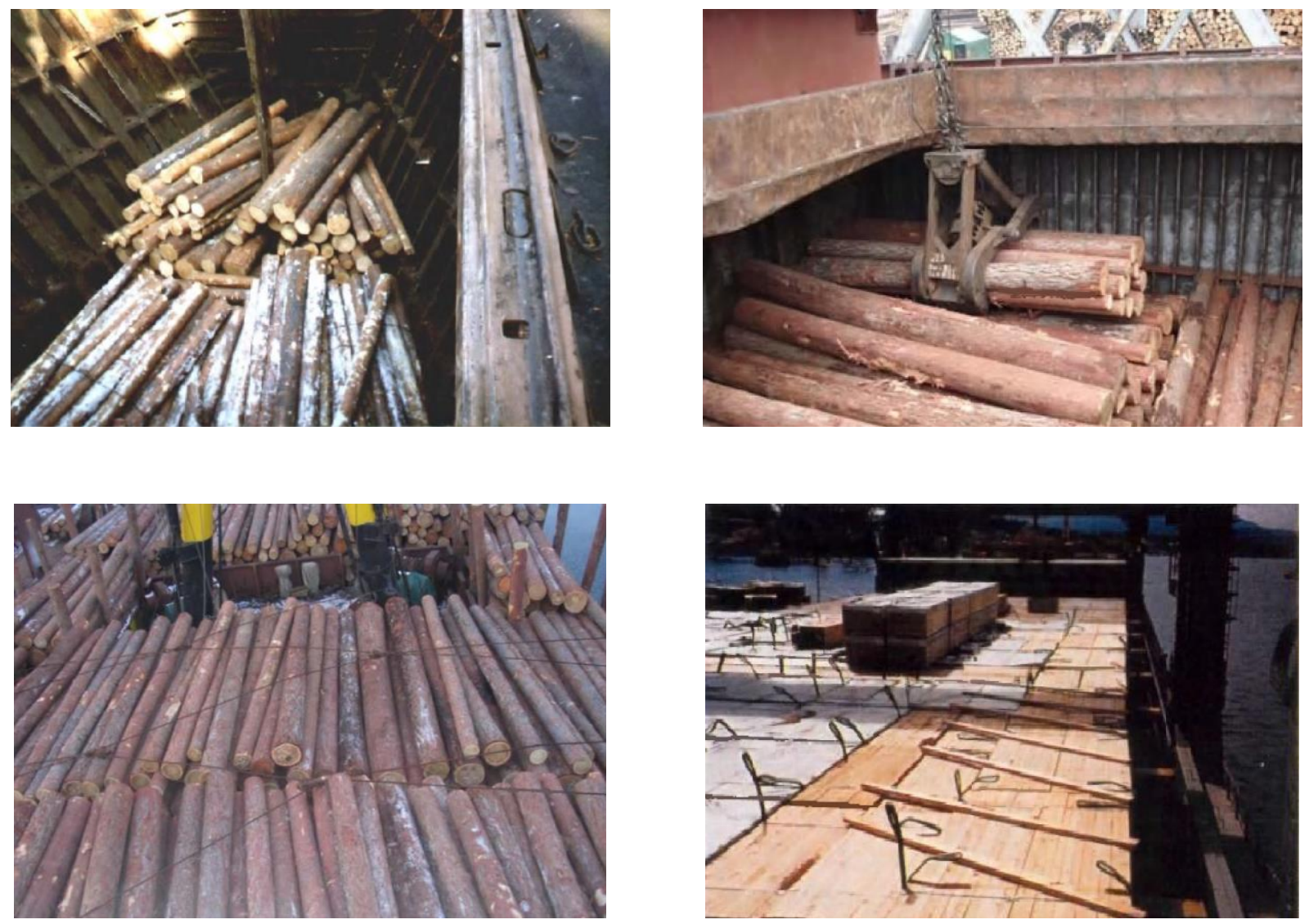

$a, \sigma$ - лесоматериалы в трюмах судна; в, г - лесоматериалы и пакетированный пиломатериал на палубе судна

Рисунок 9 - Расположение лесных грузов в трюмах и на палубе судна

Большие габаритные размеры судов лесовозов позволяют вывозить ими значительный объем лесоматериалов. Это способствует существенному сокращению денежных средств, затрачиваемых на их транспортирование, а также снижению влияния этих затрат на конечную стоимость лесоматериалов. Не смотря на это, одним из главных недостатков транспортирования лесоматериалов водным транспортом, является его низкая скорость в сравнении с другими видами транспорта. Это объясняется тем, что сопротивление движению по воде с ростом скорости движе- 
ния судов лесовозов увеличивается значительно быстрее, чем сопротивление движению ЛАТ по ЛД или вагонов по рельсам. Кроме этого, использование для транспортирования лесоматериалов водного транспорта затруднено в зимний период ледосплава, весенние паводки, а также в засушливых местах. Зимний период времени практически исключает использование водных путей для транспортирования. Период навигации для средних широт РФ, при котором возможно транспортирование лесоматериалов по водным путям может изменяться от 180 до 200 дней [5].

Дополнительно к этому необходимо отметить, что перерывы, ограничивающие использование водного транспорта требуют создания в пунктах их отправления и прибытия дополнительных складов для лесоматериалов необходимой вместимости. Кроме этого низкая скорость транспортирования лесоматериалов, а также сезонность функционирования приводят к необходимости обеспечения требуемого объема оборотных средств для эффективной работы лесозаготовительных предприятий. Также возникают дополнительные затраты на финансирование дноуглубительных работ, с целью обеспечения прохождения лесоматериалов по водным путям. Применение для транспортирования лесоматериалов водных путей ограничено или полностью исключено, в случае когда грузоотправитель и потребитель лесоматериалов не связаны между собой реками или морскими путями.

Перспективным видом транспорта, применяемым для доставки лесоматериалов по воздуху из труднодоступных участов заготовки леса в пункты потребления, является воздухоплавательные средства, включающие в свой состав вертолеты, аэростаты, дирижабли и вертостаты [9-11].

Транспортирование лесоматериалов вертолетами осуществляется в основном для перемещения древесины преимущественно ценных пород из труд-
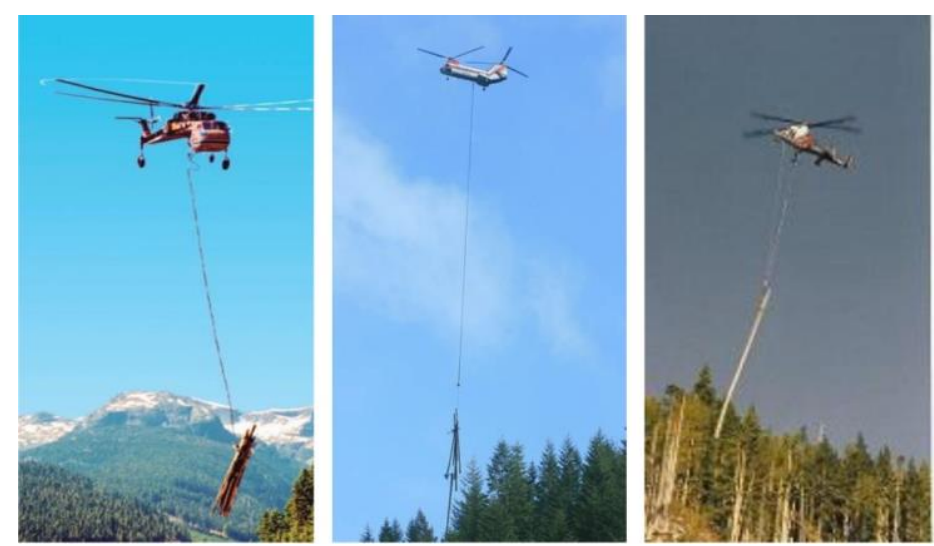

Рисунок 10 - Транспортирование лесоматериалов вертолетами нодоступных мест, обладающих ограничениями для использования других видов транспорта (рис. 10). Важной особенностью этого вида транспорта, сдерживающей его широкое применение для транспортирования лесоматериалов, является высокая себестоимость одного летного часа, что значительно увеличивает стоимость транспортирования ле- 


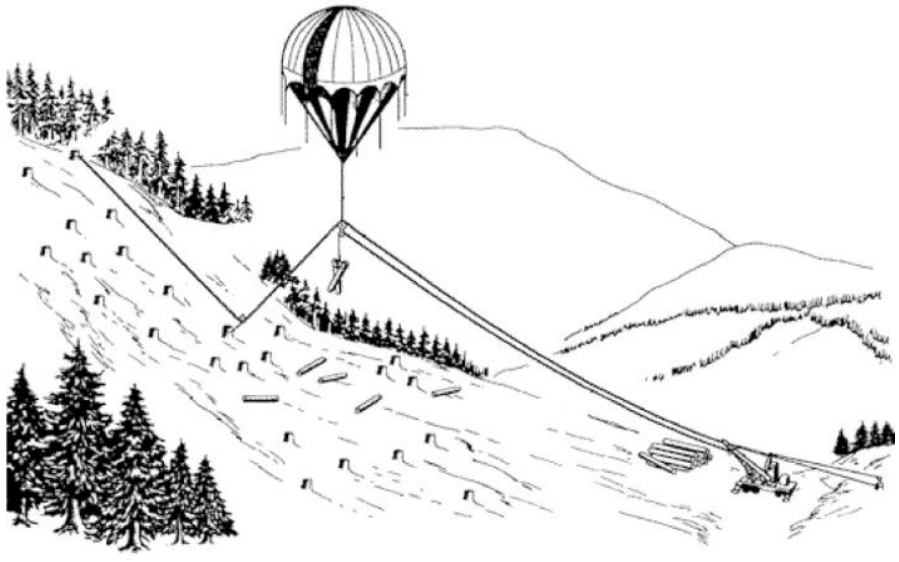

Рисунок 11 - Транспортирование лесоматериалов аэростатом соматериалов в сравнении с другими видами транспорта. Кроме этого, конструктивные особенности используемых вертолетов не позволяют повысить их грузоподъемность без значительных изменений их конструкции, в сравнении с аэростатами или дирижаблями, конструктивные особенности

оболочек которых позволяют изменить их грузоподъемность в несколько раз превышающую исходную.

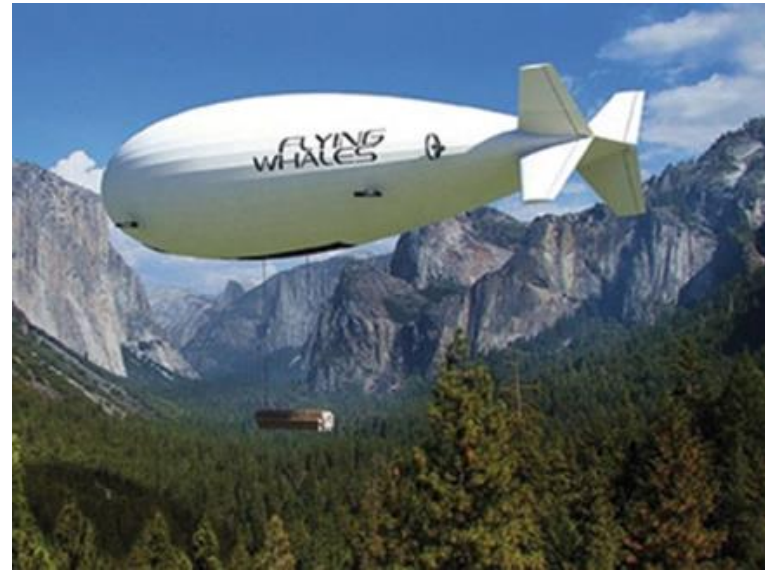

Рисунок 12 - Транспортирование лесоматериалов дирижаблем

Использование аэростатов (рис. 11) для транспортирования лесоматериалов из-за наличия в их конструкции сложных, металлоемких лебедочных механизмов, эффективно только при расстоянии транспортирования не более 1,5 км в сравнении с применением для этих целей дирижаблей (рис. 12). Транспортирование лесоматериалов дирижаблями из труднодоступных участков, с ограниченными возможностями возведения транспортных путей может осуществляться на расстояние более 100 км, что сравнимо с применением вертолетов, однако с меньшими затратами.

Одной из главных конструктивных особенностей дирижаблей, является возрастание их рентабельности при увеличении их грузоподъемности и габаритных размеров. Использование дирижаблей больших габаритных размеров позволяет им поднимать и транспортировать на дальние расстояния лесоматериалы общей массой до 2,5 тыс. тонн, не требует строительства ЛД или других наземных путей, устраняя тем самым травмирование естественных ландшафтов. Движущая сила, поднимаемая дирижабль с лесоматериалами в воздух является практически бесплатной и не требует для подъема больших затрат энергии. В сравнении с транспортированием лесоматериалов вертолетами, у дирижаблей значительно меныше удельный расход топлива и стоимость полета с лесоматериалами в расчете на единицу массы. Кроме 


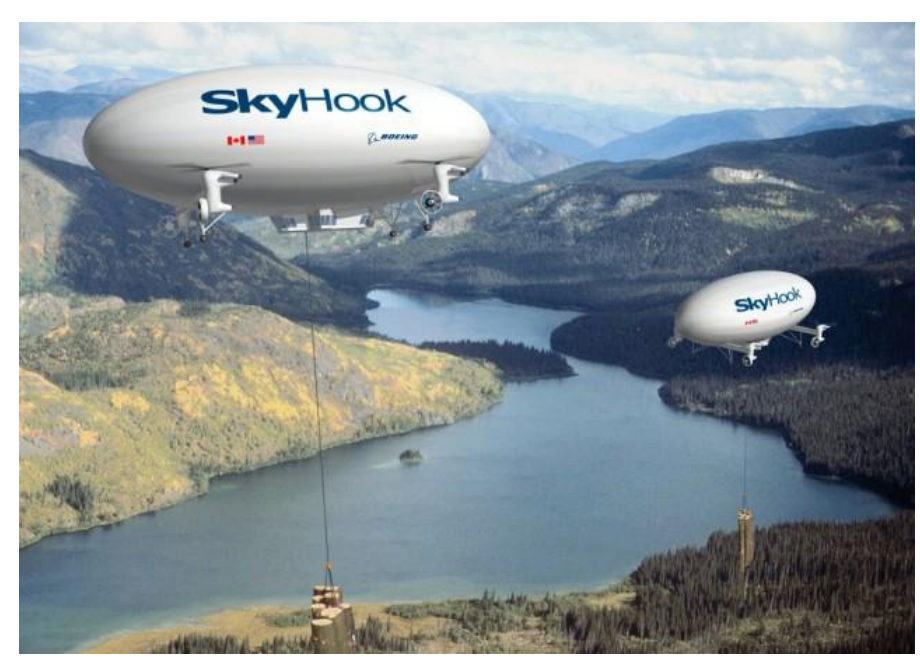

Рисунок 13 - Вертостат для транспортирования лесоматериалов

этого, возможное время нахождения дирижабля в воздухе может превышать несколько недель, для его приземления не требуется создание взлетно-посадочной полосы, достаточно установки специальной причальной мачты $[9,15]$.

Применение для транспортирования лесоматериалов вертостатов (рис. 13), представляющих собой комбинацию дирижабля с вертолетом, конструктивно выполненного с возможностью уравновешивать собственную массу с помощью аэростатических баллонов, заполненных газом легче воздуха, а также выполнять подъем и транспортирование лесоматериалов за счет винтов вертолета, позволяет устранить присущие недостатки при транспортировании лесоматериалов, как дирижаблями, так и вертолетами. Конструкции аналогичных безаэродромных летательных аппаратов, разработанных для этих целей и используемых в США имеют названия гелиостатов и аэрокрейнов, а во Франции - геликостатов.

Транспортирование лесоматериалов вертостатами в сравнении с вертолетами позволяет доставлять до потребителя лесоматериалы неограниченного размера и большой массы. Экономический эффект от применения вертостатов заключается в отсутствии затрат на строительство новых ЛД, их содержание, а также приобретение ЛАТ для вывозки лесоматериалов. Кроме этого, наличие несущих винтов, установленных на болышом расстоянии от земли позволяет исключить эрозию на посадочных площадках. Также вертостаты транспортирующие лесоматериалы могут использоваться в любом лесном регионе РФ, они обладают высокой устойчивостью и управляемостью в ветреную погоду, а также имеют возможность висеть в воздухе при скорости бокового ветра от 10 до 12 м/с без сноса их в стороны над местом погрузки и разгрузки лесоматериалов. Дополнительно к этому, применение вертостатов при транспортировании лесоматериалов более безопаснее и надежнее в сравнение с другими воздухоплавательными средствами. Данному виду транспорта не опасны отказы двигателей, существенная потеря газа в баллонах, а также незначительные поломки его конструктивных элементов, так как в случае их появления вертостат осуществляет безопасную посадку в месте погрузки или разгрузки лесомате- 
риалов. Разрабатываемые в РФ конструкции вертостатов, оснащаемые различными многооборотными тросовыми оснастками, используемыми для формирования пачек лесоматериалов требуемого объема, позволяют транспортировать лесоматериалы

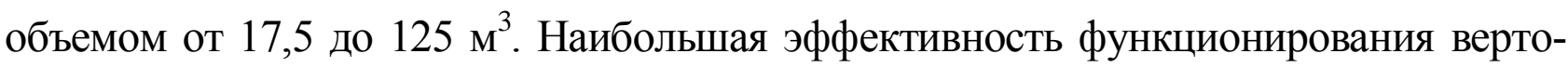
статов достигается при использовании их на крупных лесозаготовительных предприятиях с годовым объемом заготовки более $1000000 \mathrm{~m}^{3}$. Несмотря на это, применение их для транспортирования лесоматериалов имеет ограничения, которые связаны со сложными системами трансмиссии, балансировки и управления, с высокими эксплуатационными расходами, а также значительными вибрационными и динамическими нагрузками на несущие элементы конструкции вертостата [16].

Также, кроме сложностей связанных с хранением и обслуживанием воздухоплавательных транспортных средств, их недостатками, которые проявляются при неблагоприятных погодных условиях, характеризующихся метелью, снегопадами и обледенением, являются высокая трудоемкость процесса приземления, повышение собственной массы и увеличенный расход топлива по причине необходимости утепления этих транспортных средств и оснащения их устройствами обогрева.

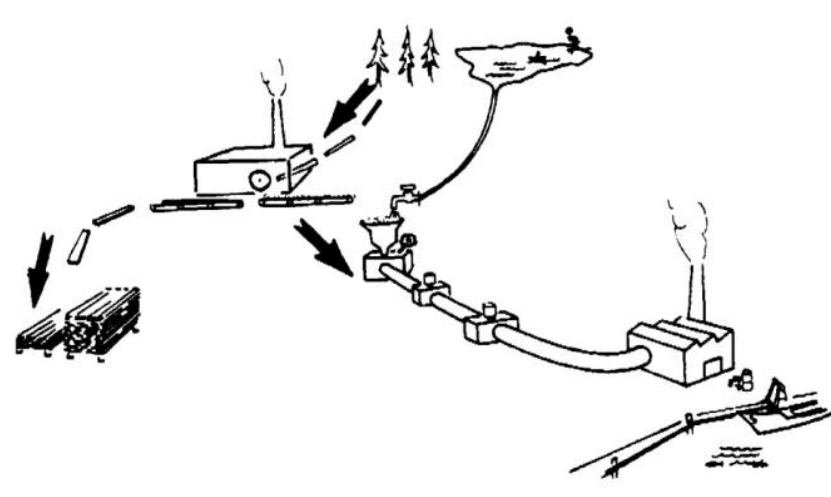

Рисунок 14 - Схема транспортирования щепы трубопроводным транспортом

Особенностями применения трубопроводного транспорта является его использование на нижних складах лесозаготовительных и деревообрабатывающих предприятий для транспортирования мелких фракций древесины, включающих в себя щепу, опилки и древесную стружку. При использовании этого вида транспорта щепа или опилки транспортируются внутри трубы с помощью воды, специальных вагонеток, а также за счет перепада давления воздуха. На рисунке 14 приведена схема транспортирования технологической щепы с водой трубопроводным транспортом, размещенным в русле непромерзающей реки. Важными достоинствами этого вида транспорта является непрерывность процесса, небольшие капитальные вложения, высокие экологические показатели, а также возможность механизации и автоматизации. Существенными недостатками, ограничивающими их широкое применение являются высокие затраты энергии, а также замерзание воды в зимний период времени $[5,16,17]$. 


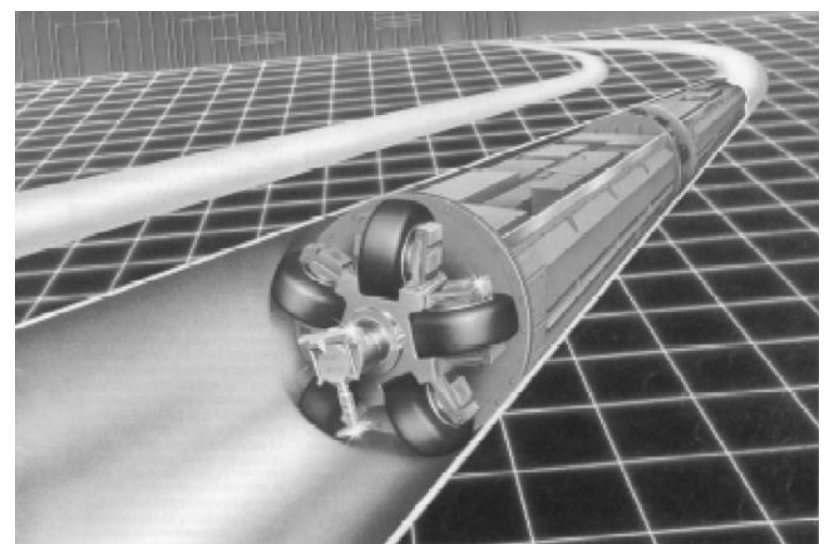

Рисунок 15 - Транспортирование щепы трубопроводным пневмокапсульным транспор-
Транспортирование щепы пневмокапсульным трубопроводным транспортом (рис. 15) осуществляется с помощью специальных капсул, каждая из которых оснащена с двух сторон специальными колесами в количестве по 5 шт. для перемещения по трубопроводу. Для транспортирования требуемого количества щепы необходимое количество капсул соединяют между собой.

Транспортирование капсул в загруженном состоянии осуществляется по одной трубе, а в порожнем состоянии по другой. После загрузки капсул на специальной станции воздух подаваемый насосом под высоким давлением перемещает капсулы по трубопроводу до точки назначения. Данный вид транспорта не нашел широкого практического применения по следующим причинам: низкая заполняемость трубопровода, только 3 \% длины трубопровода занято капсулами, 97 \% свободно, невысокая пропускная способность и высокие эксплуатационные расходы [19].

Наибольшее распространение в нашей стране получил сухопутный транспорт, которым доставляется потребителю более 80 \% лесоматериалов. Основной задачей такого вида транспорта является вывозка лесоматериалов с лесосек на нижние склады или потребителям. С учетом сооружаемого пути, по которому может осуществляться вывозка лесоматериалов, сухопутный транспорт подразделяется на канатный, рельсовый, безрельсовый транспорт, а также перспективный струнный транспорт струнный транспорт Юницкого (СТЮ). Использование рельсового транспорта (рис. 16) для вывозки лесоматериалов может осуществляться по железным дорогам узкой и широкой колеи. Основны-
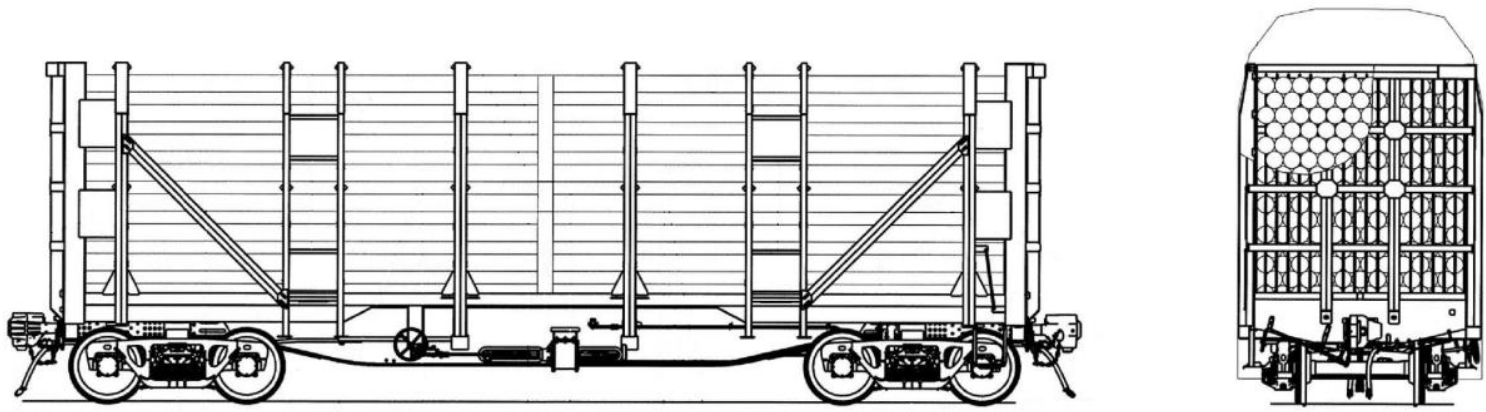

Рисунок 16 - Схема размещения круглых лесоматериалов в штабелях длиной 6 м на платформе мод. 13-9997 
ми преимуществами применения для вывозки лесоматериалов рельсового транспорта, являются: постоянство процесса вывозки лесоматериалов независимо от природно-климатических условий, времени года и суток; снижение повреждаемости вывозимых лесоматериалов; сокращение затрат в расчете на единицу объема лесоматериалов; высокая скорость вывозки и больший объем перевозимых лесоматериалов за один рейс в сравнении с речным транспортом.

Вывозка лесоматериалов железнодорожным транспортом имеет максимальную эффективность при больших расстояниях вывозки, а также при наличии у получателей лесоматериалов подъездных рельсовых путей, соединяющих их с соответствующими железнодорожными станциями. В таком случае доставка лесоматериалов потребителям выполняется непосредственно на их склады, что исключает необходимость дополнительного применения для этих целей ЛАТ. Кроме этого, важным техническим достоинством использования для вывозки лесоматериалов железнодорожного транспорта является его повышенная грузоподъемность в сравнении с ЛАТ. Также возможность вывозки большого объема лесоматериалов железнодорожным транспортом на значительное расстояние позволяет существенно сократить затраты на транспортирование в сравнении с ЛАТ. При вывозке лесоматериалов железнодорожным транспортом на короткое расстояние происходит возрастание их себестоимости в 4-5 раз. Это связано с использованием для этих целей сборных поездов менышей массы, перемещающихся с пониженной скоростью из-за более частых остановок на промежуточных железнодорожных станциях, а также с существенным удельным весом расходов на выполнение всех операций при вывозке лесоматериалов этим видом транспорта. Ограничивающим фактором при выборе типа подвижного состава железнодорожного транспорта для вывозки лесоматериалов в сравнении с ЛАТ, является только существующие конструкции платформ (рис. 17) [21].

Согласно статистике последних лет, доля лесоматериалов, перевезенных в полувагонах железнодорожным транспортом, составила 55 \%, а на платформах - 28 \%. Недостатками использования железнодорожного транспорта при вывозке лесоматериалов, способствующими росту общих сроков доставки лесоматериалов, а также возникновению дополнительных затрат, являются: большие капитальные вложения на приобретение металла для строительства 1 км рельсового пути; необходимость предварительной доставки лесоматериалов от места вырубки к месту их погрузки на вагонные платформы, а также недос- 

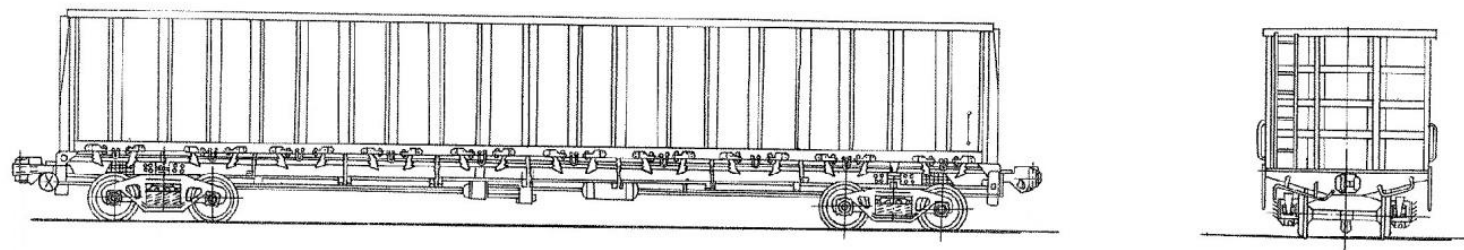

$a$
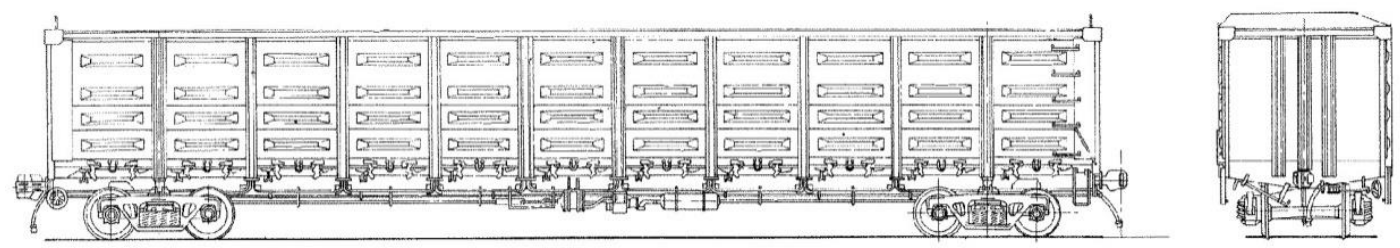

$\sigma$

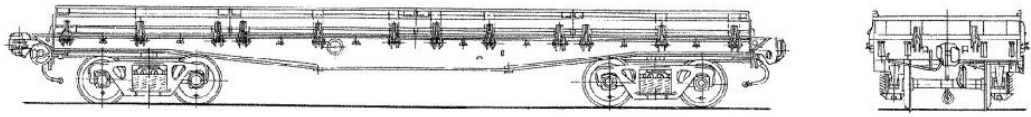

B

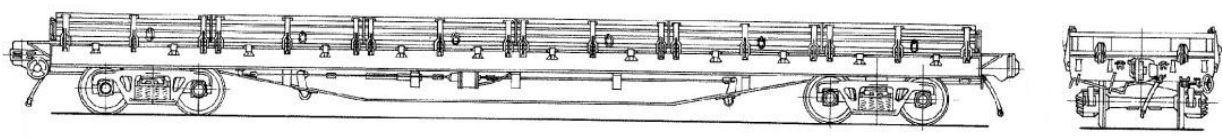

2

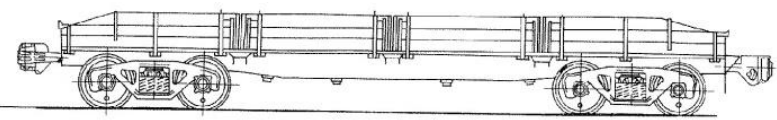

$\partial$
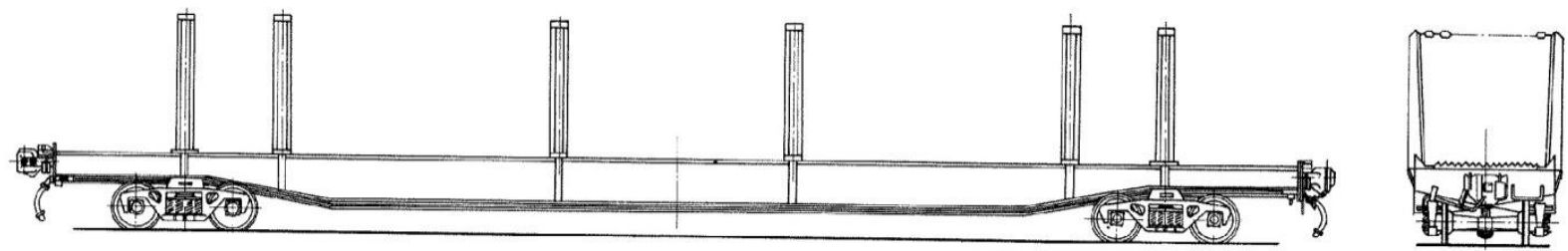

$e$
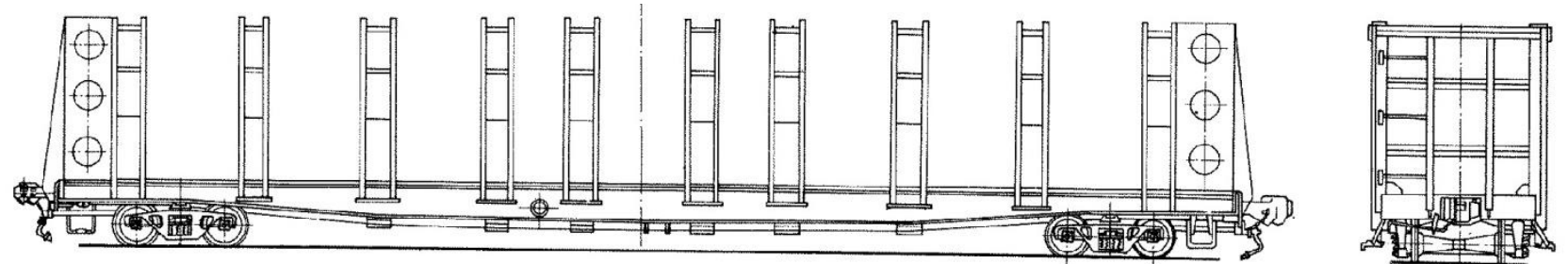

$\mathscr{C}$

$a$ - 4-осный цельнометаллический полувагон для технологической щепы, модель 220478 ; $\sigma$ - 4-осный полувагон для технологической щепы, модель 12-4004; в - 4-осная платформа с металлическими бортами, модель 13-401; 2 - 4-осная платформа увеличенной длины, модель 13-491; $\partial$ - 4-осная платформа, модель 13 -H453; $e$ - 4-осная платформа для леса в хлыстах, модель 23-469; ж - 4-осная платформа для лесоматериалов, модель 23-4000

Рисунок 17 - 4-осные полувагоны и платформы для перевозки лесоматериалов

таточная маневренность в сравнение с ЛАТ [20].

Широкое использование узкоколейных железных дорог для транспортирования лесоматериалов, а также их развитие в качестве основного вида транс- 
порта леса осуществлялось до 1960-х гг. Узкоколейные лесовозные железные дороги подразделялись на две большие группы: сплавные и примыкающие к ширококолейным магистралям. Сплавные узкоколейные железные дороги были полностью изолированы от общей железнодорожной сети страны, их центральными точками являлись сплавные пункты - поселки на реках, по которым производился лесосплав. Задачей дороги была доставка лесоматериелов с лесозаготовок на сплавной пункт. Большая часть сплавных лесовозных железных дорог была также изолирована и от круглогодичной автотранспортной сети, завоз материалов для их строительства и подвижного состава производился по так называемым автозимникам - некруглогодичным дорогам, работающим в холодное время года. С другой стороны, узкоколейные дороги, примыкающие к ширококолейным магистралям, имели своими начальными точками нормальные железнодорожные станции, на которых производилась перегрузка лесоматериалов с вагонов узкой колеи на вагоны широкой колеи. Наиболее часто используемые для транспортирования лесоматериалов вагоны сцепы узкоколейного железнодорожного транспорта приведены на рисунках 18 и 19.

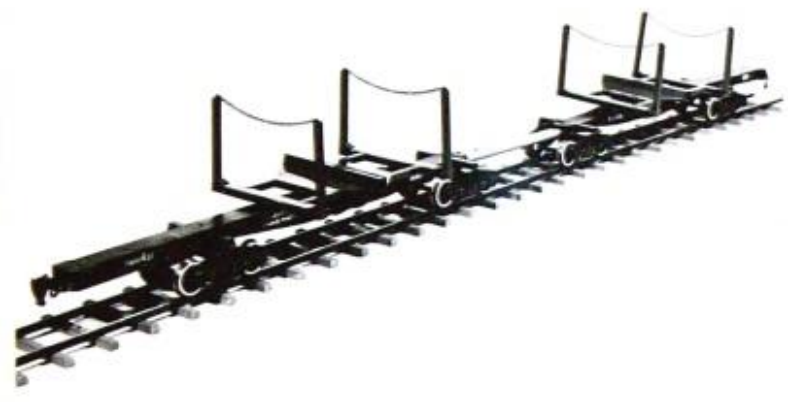

a

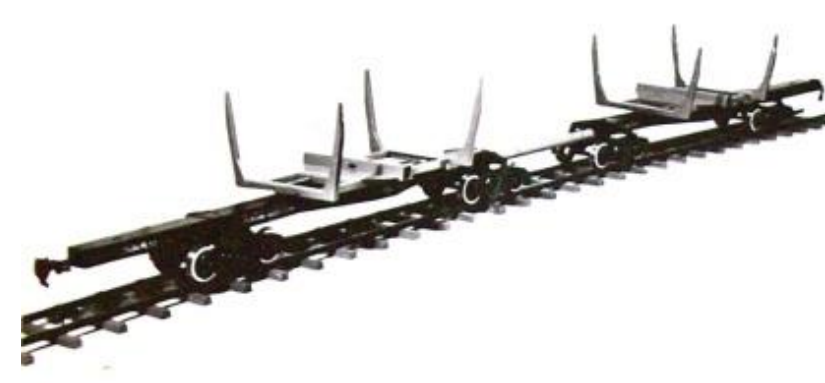

б

$a$ - вагон сцеп ЛТ-22 модель 43-082; $\sigma$ - вагон сцеп ЛТ-22 модель 43-091

Рисунок 18 - Вагоны сцепы ЛТ-22 для вывозки лесоматериалов

Несмотря на это в 1970-х гг. развитие узкоколейных железных дорог было прекращено, в связи с интенсивным развитием и внедрением ЛАТ. Это было связано с тем, что металлоемкость 1 т · км вывозки лесоматериалов по узкоколейным железным дорогам значительно превышала металлоемкость 1 т $\cdot$ км вывозки лесоматериалов ЛАТ. В настоящее время доля объема лесоматериалов вывозимых по узкоколейным железным дорогам от всего объема вывозимых лесоматериалов в год в РФ составляет менее 1 \% и продолжает с каждым годом снижаться. 

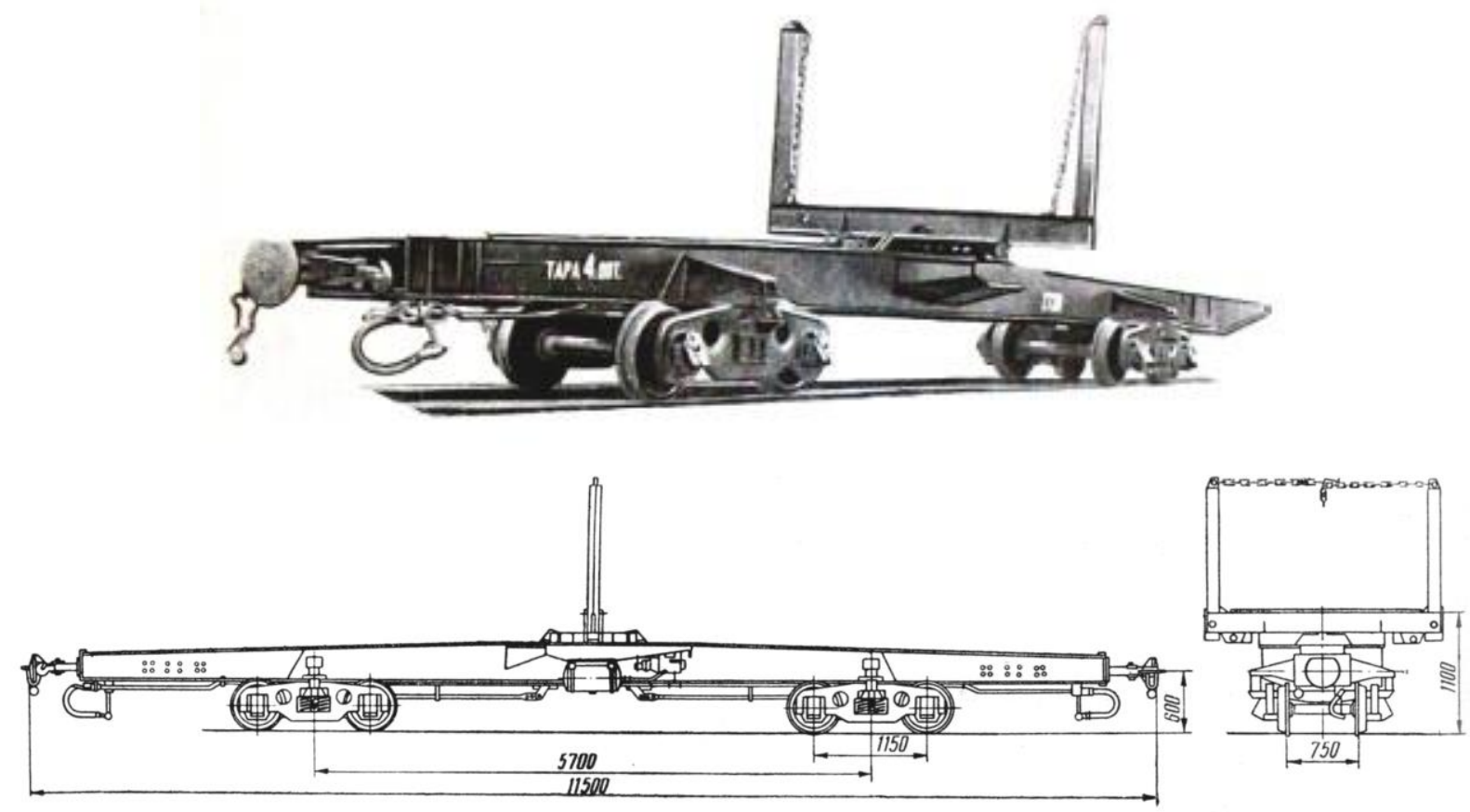

Рисунок 19 - Лесовозный вагон-сцеп ЛТ-22

Тем не менее, вывозка лесоматериалов железнодорожным транспортом по узкоколейным рельсовым путям является единственным способом круглогодичной вывозки большого объема лесоматериалов через болотистую лесопокрытую местность. Стоимость вывозки лесоматериалов таким видом транспорта в 5-7 раз ниже в сравнении с вывозкой лесоматериалов ЛАТ в таких же природно-климатических и дорожных условиях. Производительность узкоколейной железной дороги в 10-12 раз превышает производительность лесовозного автозимника. Преимуществом узкоколейной железной дороги также является сокращение затрат при возведении их на грунтах со слабой несущей способностью, а также в горной и холмистой местности [22-24].

Перспективным разрабатываемым видом транспорта для вывозки лесоматериалов является СТЮ, который представляет собой специальный юнибус или лесовозный автомобиль, конструктивно выполненные на стальных колесах, установленных на рельсах-струнах, которые закреплены на поддерживающих и анкерных опорах. Однорельсовый СТЮ с подвижными моно-юнибусами состоит из одной рельсы-струны для каждого пути, с длиной пролетов до 3000 м (рис. 20, a). Разновидностью СТЮ также является рельсо-струнная путевая структура двухрельсового СТЮ (рис. 20, б), которая жестко соединена с анкерными опорами, размещенными через каждые 1 - 


\section{Воронежский научно-технический вестник № 3(33) сентябрь 2020 г.}

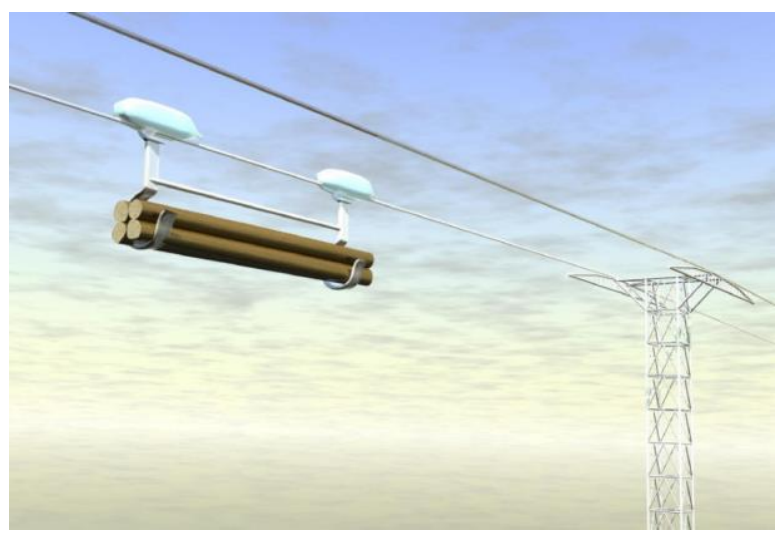

$a$

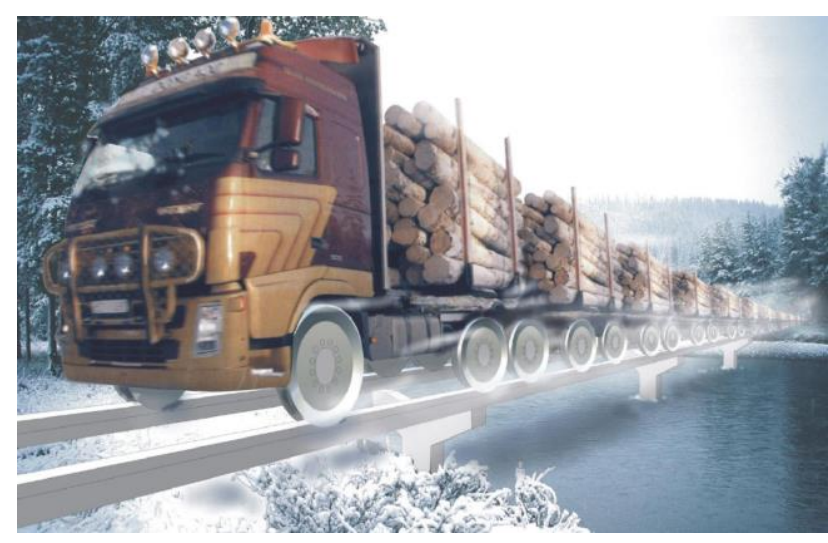

$\sigma$

$a$ - грузовая трасса однорельсового СТЮ; $\sigma$ - грузовая трасса бирельсового СТЮ

Рисунок 20 - Варианты грузовых трасс моноСТЮ для транспортирования лесоматериалов

5 км и более, а также шарнирно установлена на промежуточных опорах стойках с длиной пролетов 30-40 м. Натяжение струн в рельсах-струнах в зависимости от грузоподъемности перемещаемых транспортных средств может изменяться от 25 до 500 т [25].

Полностью автоматизированная подвесная трасса, не зависящая от рельефа местности, со специальными самоходными транспортными модулями, высокой скоростью перемещения и малым временем погрузки-разгрузки, практически не имеет конкурентов по производительности для малых (1-10 км), средних (10-50 км) и больших (свыше 50 км) расстояний. Практическое применение СТЮ позволит: снизить в 1,5-2 раза стоимость вывозки лесоматериалов в сравнении с железнодорожным транспортом и в 3-5 раз в сравнении с ЛАТ; сократить расход топлива в 1,5-2 раза в сравнении с железнодорожным транспортом и в 5-6 раз в сравнении с ЛАТ. Однако данный вид транспорта находится на стадии разработки и широкого применения еще не нашел.

В РФ около 36 \% покрытой лесом площади занимают горные леса, которые характеризуются более высокими запасами лесоматериалами, чем равнинные леса. На крутых горных склонах для транспортирования лесоматериалов широко используются канатные установки, эффективность работы которых практически не зависит от крутизны горного склона. Канатный транспорт применяют для перемещения лесоматериалов на небольшие расстояния и в малых объемах (рис. 21). К канатному транспорту относят процесс перемещения на специальных тележках лесоматериалов по натяжному между опорами несущему канату. 


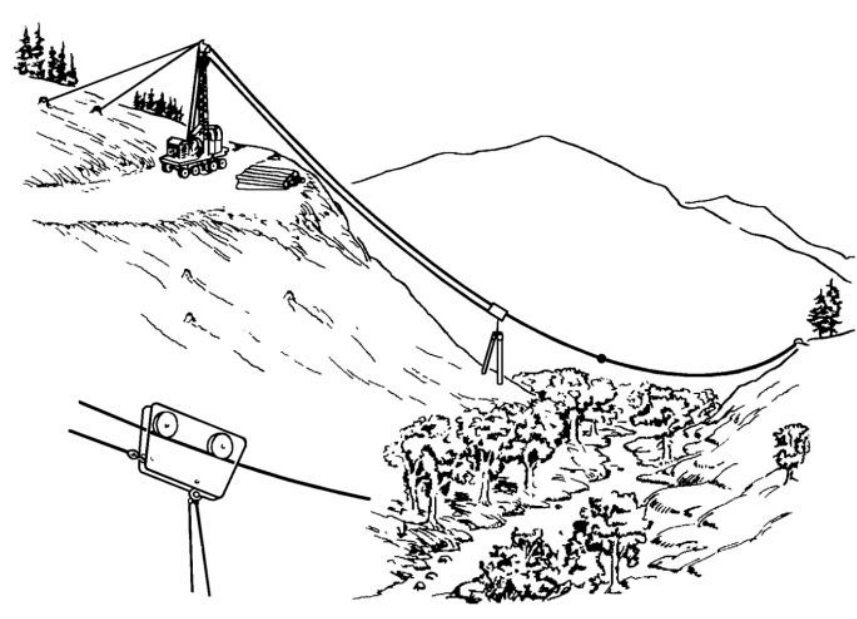

Рисунок 21 - Схема транспортирования лесоматериалов по канатной дороге [24]

Наиболее распространены в лесной промышленности подвесные канатные установки. Главное их преимущество в том, что они позволяют транспортировать лесоматериал по кратчайшему, прямому пути вдоль склона там, куда не может добраться другой вид наземного транспорта. Лесоматериалы можно перемещать даже с другого берега озера, если удастся закрепить на якорном дереве другой конец системы тросов. Канатными установками можно транспортировать как хлысты, так и сортименты, кроме этого, канатная дорога позволяет существенно снизить затраты на освоение сложных участков лесного фонда. Основным недостатком использования подвесных канатных установок для транспортирования лесоматериалов является необходимость монтирования канатной дороги на новом месте после разработки каждого участка, что приводит к снижению эффективности данного процесса [27].

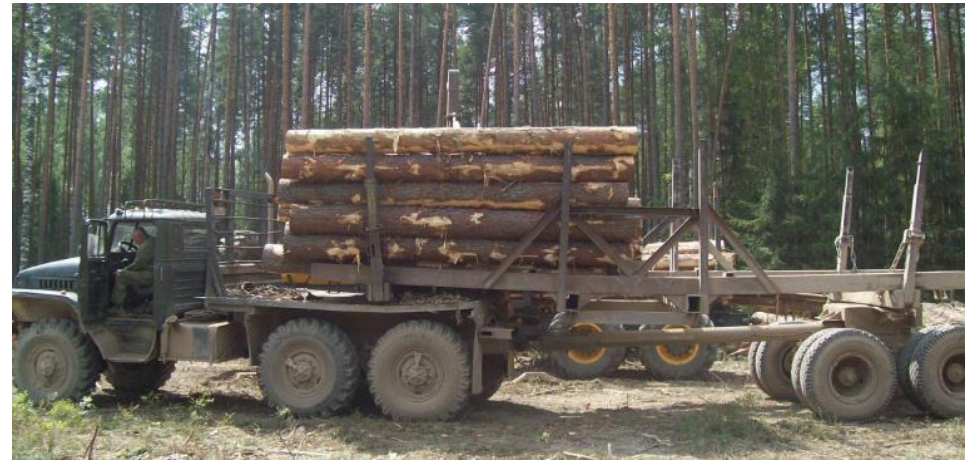

Рисунок 22 - Вывозка лесоматериалов ЛАТ

Наибольшее применение для вывозки лесоматериалов потребителям в РФ и других странах среди известных безрельсовых транспортных средств, перемещающихся по опорным поверхностям ЛД различного типа находит ЛАТ (рис. 22), который уже значительно длительное время развивается и конкурирует с другими видами транспорта, используемого в этом процессе. Преимуществами ЛАТ перед железнодорожным и внутренним водным транспортом является его высокая мобильность, маневренность, подвижность, технологическая, а также коммерческая гибкость. ЛАТ в настоящее время нет адекватной замены при вывозке лесоматериалов на расстояния от 300 до 500 км. Доля объема вывозимых лесоматериалов в год ЛАТ от общего объема транспортируемых лесоматериалов все- 
ми известными видами транспорта составляет около 48 \% [28, 32, 33].

Вывозка лесоматериалов ЛАТ на расстояние до 200 км осуществляется в 12 раз быстрее в сравнении с вывозкой лесоматериалов на тоже расстояние смешенным сообщением, выполняемым железнодорожным и автомобильным транспортом, а также в 5 раз быстрее в сравнении с вывозкой лесоматериалов на тоже расстояние железнодорожным транспортом в прямом сообщении. При вывозке же лесоматериалов на расстояние до 500 км, ЛАТ имеет преимущества в скорости доставки лесоматериалов перед сравниваемыми видами транспорта, соответственно в 7 и 3 раза. Также еще одним важным достоинство ЛАТ является возможность его подбора под размеры лесоматериалов, а не наоборот, как это выполняется с другими видами транспорта, используемыми для вывозки лесоматериалов. Эффективность функционирования ЛАТ в сравнении с водным видом транспорта и воздушным меныше зависит от природноклиматических условий. ЛАТ остается основным конкурентом при вывозке лесоматериалов перед железнодорожным транспортом. Однако, с увеличением расстояния вывозки лесоматериалов ЛАТ, его преимущество в скорости перед другими видами транспорта значительно снижается $[21,34,35]$.

Кроме этого эффективное функционирование ЛАТ требует большого количества доступных для всех пользователей ЛД, расположенных на территории РФ, строительство и содержание которых в большинстве случаев обходится очень дорого. К тому же ЛАТ имеет ограниченную грузоподъемность и функционирует за счет использования специального топлива. Существенным недостатком ЛАТ является его неполное использование в связи с тем, что до складов или мест заготовки он перемещается пустым. Это приводит к тому, что затраты на вывозку лесоматериалов составляют 20 \% их стоимости и устранить данную проблему невозможно, так как перерабатывающие предприятия и площадки лесозаготовок всегда располагаются на значительном удалении [36].

\section{Выводы}

В настоящее время для транспортирования лесоматериалов задействованы такие виды транспорта, как сухопутный, водный, трубопроводный и воздушный, а также их разновидности. Использование каждого вида транспорта имеет свои особенности, важные преимущества и существенные недостатки.

Изучение основных особенностей различных видов транспорта, используемых в процессе транспортирования или вывозки лесоматериалов, позволил выполнить их сравнение по основным показателям эффективности (табл. 1) [29-31]. 
Таблица 1 - Сравнительная оценка показателей эффективности различных видов транспорта

\begin{tabular}{|c|c|c|c|c|c|}
\hline \multirow[b]{2}{*}{$\begin{array}{c}\text { Показатели } \\
\text { эффектив- } \\
\text { ности }\end{array}$} & \multicolumn{5}{|c|}{ Различные виды транспорта } \\
\hline & ЛАТ & $\begin{array}{c}\text { Железнодо- } \\
\text { рожный } \\
\text { транспорт }\end{array}$ & $\begin{array}{c}\text { Воздушный } \\
\text { транспорт }\end{array}$ & $\begin{array}{c}\text { Речной } \\
\text { транспорт }\end{array}$ & $\begin{array}{c}\text { Морской } \\
\text { транспорт }\end{array}$ \\
\hline $\begin{array}{c}\text { Скорость } \\
\text { вывозки ле- } \\
\text { соматериа- } \\
\text { лов }\end{array}$ & высокая & высокая & $\begin{array}{c}\text { очень } \\
\text { высокая }\end{array}$ & низкая & низкая \\
\hline $\begin{array}{c}\text { Себестои- } \\
\text { мость вы- } \\
\text { возки лесо- } \\
\text { материалов }\end{array}$ & средняя & низкая & высокая & низкая & низкая \\
\hline $\begin{array}{l}\text { Пропускная } \\
\text { способность }\end{array}$ & невысокая & высокая & малая & высокая & $\begin{array}{c}\text { неограничен- } \\
\text { ная } \\
\end{array}$ \\
\hline $\begin{array}{c}\text { Регуляр- } \\
\text { ность вы- } \\
\text { возки лесо- } \\
\text { материалов }\end{array}$ & $\begin{array}{c}\text { контролиру- } \\
\text { емая }\end{array}$ & стабильная & $\begin{array}{c}\text { ограничива- } \\
\text { ется погод- } \\
\text { ными услови- } \\
\text { ями } \\
\end{array}$ & сезонная & $\begin{array}{c}\text { ограничена в } \\
\text { некоторых } \\
\text { случаях }\end{array}$ \\
\hline $\begin{array}{l}\text { Объем вы- } \\
\text { возки лесо- } \\
\text { материалов }\end{array}$ & небольшой & большой & небольшой & большой & большой \\
\hline $\begin{array}{c}\text { Дальность } \\
\text { вывозки ле- } \\
\text { соматериа- } \\
\text { лов }\end{array}$ & небольшая & $\begin{array}{c}\text { внутрикон- } \\
\text { тиненталь- } \\
\text { ная }\end{array}$ & $\begin{array}{c}\text { неограничен- } \\
\text { ная }\end{array}$ & $\begin{array}{c}\text { внутри водно- } \\
\text { го бассейна }\end{array}$ & $\begin{array}{c}\text { межконтинен- } \\
\text { тальная }\end{array}$ \\
\hline $\begin{array}{c}\text { Потреб- } \\
\text { ность в спе- } \\
\text { циальных } \\
\text { терминалах }\end{array}$ & не требуется & $\begin{array}{c}\text { требуются } \\
\text { терминалы } \\
\text { на ж/д } \\
\text { станции } \\
\end{array}$ & $\begin{array}{l}\text { требуются } \\
\text { аэропорты }\end{array}$ & $\begin{array}{c}\text { требуются } \\
\text { терминалы на } \\
\text { пристани }\end{array}$ & $\begin{array}{c}\text { требуются } \\
\text { портовые хо- } \\
\text { зяйства }\end{array}$ \\
\hline $\begin{array}{c}\text { Потреб- } \\
\text { ность в спе- } \\
\text { циальной } \\
\text { сети дорог } \\
\text { или путей }\end{array}$ & требуется & требуется & не требуется & не требуется & не требуется \\
\hline
\end{tabular}

Кроме этого, анализ особенностей функционирования рассмотренных видов транспорта, используемых в процессе вывозки и транспортирования лесоматериалов, позволил выявить важные преимущества ЛАТ перед другими видами транспорта, которые заключаются в следующем:

- обладая высокой скоростью движения, маневренностью, подвижностью при преодолении крутых подъемов, прохождении кривых, ЛАТ, используемый для вывозки лесоматериалов позволяет оперативно сосредоточить его необходимое количество требуемой компоновки в нужном месте, внести коррективы в маршрут следования, произвести погрузку и выгрузку лесоматериалов практи- 
чески у любого лесозаготовительного цеха или потребителя;

- при применении ЛАТ для вывозки лесоматериалов потребителям отпадает необходимость в использовании смешенного сообщения несколькими видами транспорта, в выполнении дополнительных перегрузочных операций с лесоматериалами, что исключает возникновение дополнительных расходов времени и материальных средств;

- в отличие от основного своего конкурента - железнодорожного транспорта, ЛАТ позволяет снизить затраты на выполнение погрузочноразгрузочных работ, а также обладает более низкой капиталоемкостью основных средств производства, заключающейся в меньших капитальных вложениях в строительство ЛД при малых потоках лесоматериалов в сравнении с прокладкой рельсовых путей. Кроме этого ЛАТ способен более гибко реагировать на меняющиеся дорожные условия в сравнении с железнодорожным транспортом. В случае возникновения на пути следования железнодорожного транспорта в процессе транспортирования лесоматериалов ремонтных работ, ему приходится останавливаться на неопределенное время и ждать окончания их выполнения. ЛАТ же, заранее предупрежденный о проведении ремонтных работ на ЛД объезжает этот участок, затратив на ожидание незначительное количество времени. Также использование ЛАТ позволяет контролировать месторасположение вывозимых лесоматериалов на всем пути вывозки, в отличие от железнодорожного транспорта, контроль которого выполняется только по прибытию его на станцию;

- в сравнении с морским транспортом, применяемым для транспортирования лесоматериалов, использование ЛАТ в меньшей степени зависит от географических особенностей и метеорологических условий, а также обладает меньшей капиталоемкостью основных средств производства в сравнении со значительными капитальными вложениями, затрачиваемыми на создание и функционирование портового хозяйства и транспортного флота;

- в отличие от внутреннего водного транспорта, используемого для транспортирования лесоматериалов, ЛАТ в меньшей степени зависит от сезонности и времени функционирования, обладает в 2-3 раза большей скоростью вывозки лесоматериалов. Это объясняется наличием ступенчатости глубин рек, ограничивающих их пропускную способность, а также за счет увеличения расстояния маршрутов вывозки лесоматериалов по причине извилистости водного пути и судового хода; 
- в сравнении с воздушным транспортом, применение ЛАТ имеет меньшую стоимость вывозки лесоматериалов, а также большую грузоподъемность;

- вывозка лесоматериалов ЛАТ обеспечивает своевременность доставки в тех случаях, когда она была запланирована. Для того, чтобы осуществить вывозку лесоматериалов железнодорожным или морским транспортом необходимо за несколько недель забронировать за собой грузоместо и решить все формальные вопросы. Вывозку же лесоматериалов подходящим ЛАТ можно выполнить в более короткий срок;

- только ЛАТ имеет возможность осуществлять вывозки лесоматериалов смешенными видами транспорта. Даже в случае, если основную часть маршрута лесоматериалы транспортируются железнодорожным или морским транспортом, без ЛАТ не обойтись, так как только им можно доставить лесоматериалы непосредственно потребителям или для дальнейшего транспортирования в порт или железнодорожную станцию. Именно с учетом этих особенностей ЛАТ имеет высокую долю в общей структуре грузоперевозок и является самым распространенным видом транспорта для вывозки лесоматериалов.

Кроме выявленных преимуществ были определены и существенные недостатки ЛАТ перед другими видами транспорта. Основными из них являются: отсутствие или низкое обустройство ЛД во многих лесозаготовительных районах РФ; значительный расход топлива; небольшая грузоподъемность, недостаточная надежность, вызванная воздействием существенных по величине динамических нагрузок, возникающих при движении ЛАТ по недостаточно обустроенным ЛД; загрязнение окружающей среды; высокие затраты на вывозку лесоматериалов, оказываемые значительное воздействие на их конечную стоимость, а также на конкурентоспособность с другими видами лесовозного транспорта; снижение производительности при увеличении расстояния вывозки; риски возникновения аварий на ЛД; высокая зависимость ЛАТ от дорожных и климатических условий, замедляющая или приостанавливающая процесс вывозки лесоматериалов, увеличивая или срывая сроки их доставки. Устранение этих недостатков за счет повышения эффективности функционирования ЛАТ путем использования в их конструкции перспективных научнотехнических решений позволит снизить затраты на вывозку лесоматериалов, сократить их конечную стоимость, улучив эффективность работы лесозаготовительных предприятий, а также конкурентоспособность ЛАТ с другими видами транспорта лесоматериалов. 


\section{Резюме}

Выполненный анализ различных видов транспорта, задействованных в настоящее время в процессе транспортирования лесоматериалов потребителям, позволил на основе их конструктивных особенностей и условий эксплуатации выявить, как положительные, так и отрицательные стороны использования. Это дает возможность при сравнении с другими видами транспорта выделить важные преимущества ЛАТ, условия при которых его использование является наиболее выгодным для ЛП при осуществлении своих функций, а также обосновать необходимость дальнейшего совершенствования ЛАТ с целью повышения его эффективности.

\section{СПИСОК ЛИТЕРАТУРЫ}

1 Иевлева, А. А. Анализ эффективности использования различных видов транспорта при выполнении международных перевозок грузов в направлении Европа-Азия / А. А. Иевлева // Транспортное дело России, 2010, № 2. - С. 111-114.

2 Маликова, Э. Р. Пространственные особенности изучения морских портов России / Э. Р. Маликова, Т. П. Гришин, А. Р. Ахунов, 3. Р. Гильванова // Fundamental research, № 5. - 2017. - C. 172-177.

3 Субботин, А. С. Основы гидротехники / А. С. Субботин. - Л. : Гидрометеоиздат, 1983. - 318 с.

4 Васильев, В. В. Анализ факторов, определяющих эффективность плотового сплава древесины / В. В. Васильев // Лесотехнический журнал, № 3, 2011. - C. 71-80.

5 Пошарников, Ф. В. Технология и техника в лесной промышленности / Ф. В. Пошарников ; М-во образования и науки Рос. Федерации, Фед. гос. бюджет. образоват. учреждение высш. проф. образования «Воронеж. гос. лесотехн. акад.». - Изд. 2-е, перераб. и доп. - Воронеж, 2012. - 296 с.

6 Динамика грузоперевозок в России. Бюллетень социальноэкономического кризиса в России, декабрь 2015. - 24 с.

7 Транспорт леса. в. 2 т. Т. 2. Лесосплав и судовые перевозки : учебник для студ. высш. учеб. заведений / М. М. Овчинников, В. П. Полищук, Г. В. Григорьев. - М. : Издательский центр «Академия», 2009. - 208 с.

8 Снопков, В. И. Перевозка грузов морем. Справочное пособие, издание второе, переработанное и дополненное, -319 с.

9 Леса и дирижабли. - Режим доступа : http://omskmark.moy.su/publ/essayclub/novator_ru/2016_v_r_pljuhin_shalaevvs/94-1-0-2763\#t20c/ - Загл. с экрана.

10 Abdullah E. Akay, Ebru Bilici Helicopter Logging Method for Reduced 
Impact Timber Harvesting Operations Eur J Forest Eng 2016, 2(1) : 48-53.

11 Olga Feldman The Possible Use of Airships in the Scottish Forest Industries Transport Innovation Research Paper, 2014. - 16 p.

12 Лесная энциклопедия : В 2-х т. / Гл. ред. Воробьев Г. И. ; Ред. Кол. : Анучин Н. А., Атрохин В. Г., Виноградов В. Н. и др. - М. : Сов. энциклопедия, 1985. $-563 \mathrm{c}$.

13 Транспорт леса : учебник в двух томах. Том 1. Сухопутный транспорт. под. редакцией Э. О. Салминена. - Москва, 2009. - 367 с.

14 Бернотас, Р. В. Математическая модель производительности аэростатических транспортных систем при освоении труднодоступных лесных территорий / Р. В. Бернотас // Инженерный вестник Дона, № 3, 2015.

15 Хлызов, Д. В. Использование дирижаблей в транспортировке леса / Д. В. Хлызов, А. П. Мохирев. Режим доступа : http://www.science-bsea.bgita.ru/2010/les_2010/xlysov_isp.htm. - Загл. с экрана.

16 Рохленко, Д. Б. Как и зачем рубят лес? / Д. Б. Рохленко. - М. : Лесн. пром-сть, 1988. - 150 с.

17 Wood chips production, handling, transport. Second (updated) edition. Food and agricukture organization of the united nations, Rome, 1976. - $144 \mathrm{p}$.

18 Пальникова, Е. Н. Состояние и перспективы развития грузовых автомобильных перевозок в Российской Федерации / Е. Н. Пальникова, Ю. А. Хегай.

19 Henry, Liu Pneumatic Capsule PipelineBasic Concept, Practical Considerations, and Current Research // Mid-continent transportation symposium 2000 proceedings. - pp. 230-234.

20 Кривов, С. И. Перспективы транспортировки лесных грузов / С. И. Кривов // Наука и транспорт, 2007. - 30-32.

21 Лукьянова, О. О конкуренции железнодорожного и автомобильного транспорта на рынке грузовых перевозок / О. Лукьянова, Ф. Хусаинов // Научнопрактический альманах «Вектор транспорта», № 2, 2014. - С. 28-43.

22 Применение узкоколейных железных дорог в лесном хозяйстве : историческая практика, современность, перспективы : Режим доступа : http://wood-prom.ru/analitika/primenenie-uzkokoleynykh-zheleznykh-dorog-v-lesnom. - Загл. с экрана.

23 Котилко, В. В. Транспортные системы узкой колеи : возможности комплексного развития лесных регионов / В. В. Котилко, А. Г. Фарков // Региональная диагностика. - С. 86-93.

24 Котилко, В. В. Методология и механизмы развития и двойного использования транспортной инфраструктуры лесного комплекса / В. В. Котилко, А. Г. Фарков // Региональная экономика : теория и практика. Экономика и природопользование, 11(290). - 2013. - С. 23-29.

25 Эскизная проработка анкерных и поддерживающих путевых опор, 
станций, сервисных депо и определение общетехнических показателей будущих трасс СТЮ для условий ХМАО-Югры, Москва 2017 - 157 с.

26 Минаев, А. Н. О необходимости возрождения водного транспорта леса / А. Н. Минаев, В. А. Кацадзе / Актуальные направления научных исследований XXI века : теория и практика. 2015. - Т. 3. - № 2-2 (13-2). - С. 252-255.

27 Ничипорович, А. А. Канатные установки для трелевки и транспортировки леса в горах / А. А. Ничипорович, К. Е. Овчаров. Режим доступа : http://lsdinfo.org/kanatnye-ustanovki-dlya-trelevki-i-transportirovki-lesa-vgorax/. - Загл. с экрана.

28 Некрасов, Д. И. Разработка методики выбора лесовозных автомобилей по технико-эксплуатационным показателям / Д. И. Некрасов // дисс. на соиск. учен. степ. к.т.н., спец. 05.21.01, Екатеринбург, 2014. - 175 с.

29 Правдина, Н. В. Транспортное обеспечение коммерческой деятельности / Н. В. Правдина // Учебно-методическое пособие. - Ульяновск : УлГТУ, 2007. - 95 с.

30 Кочинов, Ю. А. Транспортное обеспечение коммерческой деятельности / Ю. А. Кочинов, Т. В. Кочинова // Учебное пособие. - Пермь : Изд-во «ОТ и ДО». 2014. - 116 с.

31 Преимущества и недостатки автомобильных грузоперевозок. Режим доступа : https://trans.ru/education/spravochnik-logista/preimushchestva-i-nedostatki-avtomobilnyh-gruzoperevozok.html. - Загл. с экрана.

32 Сушков, С. И. Разработка модели транспортной системы в лесной отрасли / С. И. Сушков, В. Н. Бухтояров, Л. В. Болотских, Т. В. Каратаева // Строительные и дорожные машины, 2018, № 6. - С. 40-42.

33 Курьянов, В. К. Экспериментальные исследования тормозной динамики лесовозных автопоездов / В. К. Курьянов, О.Н.Бурмистрова // Вестник Московского Государственного Университета Леса - Лесной Вестник, 2017, № 4. - C. 105-106.

34 Бурмистрова, О. Н. К вопросу определения зависимости скорости движения автомобиля от расстояния видимости на кривой в плане / О. Н. Бурмистрова, Е. В. Пластинина, О. М. Тимохова // Фундаментальные исследования, 2015, № 2-10. - С. 2074-2078.

35 Кондрашова, Е. В. Мероприятия для обеспечения надежности лесовозных автопоездов в процессе их эксплуатации / Е. В. Кондрашова, И. В. Четверикова // Леса России в XXI веке. Материалы III Международной научнопрактической интернет-конференции, Санкт-Петербург, 2010. - С. 214-217.

36 Афоничев, Д. Н. Повышение эффективности использования автопоездов на вывозке лесоматериалов из лесосек / Д. Н. Афоничев, В. А. Морковин, С. М. Гоптарев // Актуальные направления научных исследований XXI века : Теория и практика, 2018, Том 6, № 4(40). - С. 133-139. 